\title{
Spatial and temporal distribution of Amphipoda associated with mussel beds from the Bay of Santos (Brazil)
}

\author{
Claudia Maria Jacobi \\ Department of Zoology, University of São Paulo, CP 20520 Sāo Paulo, SP, Brazil
}

\begin{abstract}
Effects were determined of some abiotic factors on the patterns of abundance and diversity of amphipods associated with Perna perna (L.) beds. Observations were conducted at 2 sites subjected respectively to high and low degrees of wave exposure. The sampling program combined the following 4 environmental aspects: seasonal effects, wave action, vertical zonation and tide level. Sixteen species were found, of which 7 occurred only at the exposed site. The lowest values of density and number of species corresponded to the protected site; high values characterized samples from the exposed site. Jassa falcata dominated at the exposed site but was absent at the protected mussel bed. The dominant species common to both stations were: Elasmopus brasiliensis, E. pectenicrus and Hyale sp. 1. The distribution of amphipods appeared to be a function of 3 main factors, as shown by correspondence analysis: structural heterogeneity of the mussel bed (related to wave action), vertical zonation, and desiccation. Accordingly, cluster analysis pointed out wave action and zonation as the 2 key factors affecting similarity of samples. The cluster analysis of species showed few cases of high similarity and when so, the amphipods differed in life style. This niche partition partially explains coexistence of the amphipod assemblage in the mussel beds. Direct effects of wave impact seemed less important than its side effects (e.g. sedimentation) as regards selection of species, and this was related to the physical protection of the mussel mats
\end{abstract}

\section{INTRODUCTION}

Amphipods are among the most numerous and diverse components of littoral marine invertebrate communities. The group is extremely heterogeneous as regards life styles and feeding strategies (Biernbaum 1979). A great number of species seem to colonize only substrates of a certain structural complexity (Dean 1981), or are usually most abundant on highly heterogeneous habitats (Stoner 1980). Because of their complex physical structure, macrophytes have proved to be suitable substrates for the establishment of amphipods, and have indeed been the object of extensive studies (Fenwick 1976, Moore 1978, Nelson 1979 , Edgar 1983, McBane \& Crocker 1983, Stoner 1985). Amphipod communities have received less attention when associated with other biological substrates as, for example, mussel beds. Though these may not seem at first sight to be adequate shelters on account of the small amount of entangled or filamentous surfaces, amphipods are not excluded from these habitats. Fernandes (1981) mentioned the existence of a rich amphipod assemblage - particularly at exposed sides in natural mats of the brown mussel Perna perna (L.) near the Cabo Frio upwelling region (Southern Brazil), and the group was numerically dominant in the $P$. perna community of Ilha das Palmas (Jacobi in press).

It is well known that biological substrates are affected by both biotic and abiotic factors, and that this will modify the composition of the faunal associates (Hagermann 1966, Masunari 1982). The present study was designed to investigate the community of amphipods in Perna perna beds and focuses on the effect of some abiotic factors - namely wave energy, season, vertical zonation and tide level - both on the mussel beds and on the patterns of abundance and diversity of amphipods.

\section{MATERIAL AND METHODS}

Site description. The study was conducted on a small island known as Ilha das Palmas, at the entrance of the Bay of Santos $\left(24^{\circ} 00^{\prime} 30^{\prime \prime} S, 45^{\circ} 19^{\prime} 40^{\prime \prime} \mathrm{W}\right)$, State of São 
Paulo, Brazil (Fig. 1). The climate in the region is hot and wet throughout the year, with annual mean temperatures over $20^{\circ} \mathrm{C}$ and no dry season. The proximity of the port of Santos affects the quality of the water in the bay, and domestic sewage contributes to its eutrophization. The tides are of a mixed pattern (uneven semidiurnal cycles) and the tidal range is $1.8 \mathrm{~m}$. Salinity variations were moderate during the study period (April 1982 through March 1983), with a range of 27 to $31 \%$. Water temperature showed extremes of 17.5 and $26.0^{\circ} \mathrm{C}$.

During the period considered, mussel beds occupied the mid-and low-intertidal zones all around the island, except for its NW and E sides, where mytilids were found solitary or in small patches. The 2 mussel beds upon which the study was based were located at the $\mathrm{N}$ (Station $\mathrm{P}$, protected) and $\mathrm{S}$ (Station $\mathrm{E}$, exposed to oceanic winds) of the island (Fig. 1, detail). Partly because of the difference in wave energy, the mats exhibited distinct microtopographic aspects. The structure of the protected mussel bed was compact, with individuals distributed in practically one layer. The mat retained large quantities of sediment which obliterated cavities and produced a tight arrangement. Conversely, the exposed mussel bed showed a loose multilayered structure with large, abundant interstices and little sediment.

Sampling program and data treatment. Samples of $100 \mathrm{~cm}^{2}$ were scraped off with a spatula from the upper and lower areas of the mussel beds (at approximately 15 to $20 \mathrm{~cm}$ from the borders), during low and high tides in July 1982 (winter) and January 1983 (summer).
After sorting out all the associated organisms, the displacement volume of each patch was measured, as well as the sediment volume (following the removal of mussels and byssal threads). Medium-sized grains predominated at both sites (Jacobi in press). Each sample was treated as a separate collection, as the number of replicates per combination of factors was low (3). The Stn $\mathrm{P}$ samples collected in summer were not included in this work, as the mussel bed at this site was severely damaged by human predation shortly after the winter sampling.

Two types of multivariate analysis were performed on the data. Owing to the nature of the original data matrix (samples $\times$ species) emphasis was placed on correspondence analysis (Hill 1974, Legendre \& Legendre 1984), which associates the points of a contingency table by means of the Chi square distance. This ordination method is less affected than others by abundance of species, density and profile of samples, and double absences (Chardy et al. 1976). To help delimit the species and sample groupings in the factorial planes, a cluster analysis was also performed. Similarity matrices of samples and of species were constructed with base on Morisita's $C_{\lambda}$ Index (discussed in Wolda 1981), and clustered in dendrograms by the WPGMA technique (Legendre \& Legendre 1984). Only 14 of the 16 species found were considered for the cluster and correspondence analysis. Erichthonius brasiliensis (Dana) and Hyale sp. 3 were excluded because of their very low abundance and frequency. All other amphipods were included independently of their abundance. The analyses were carried out on the

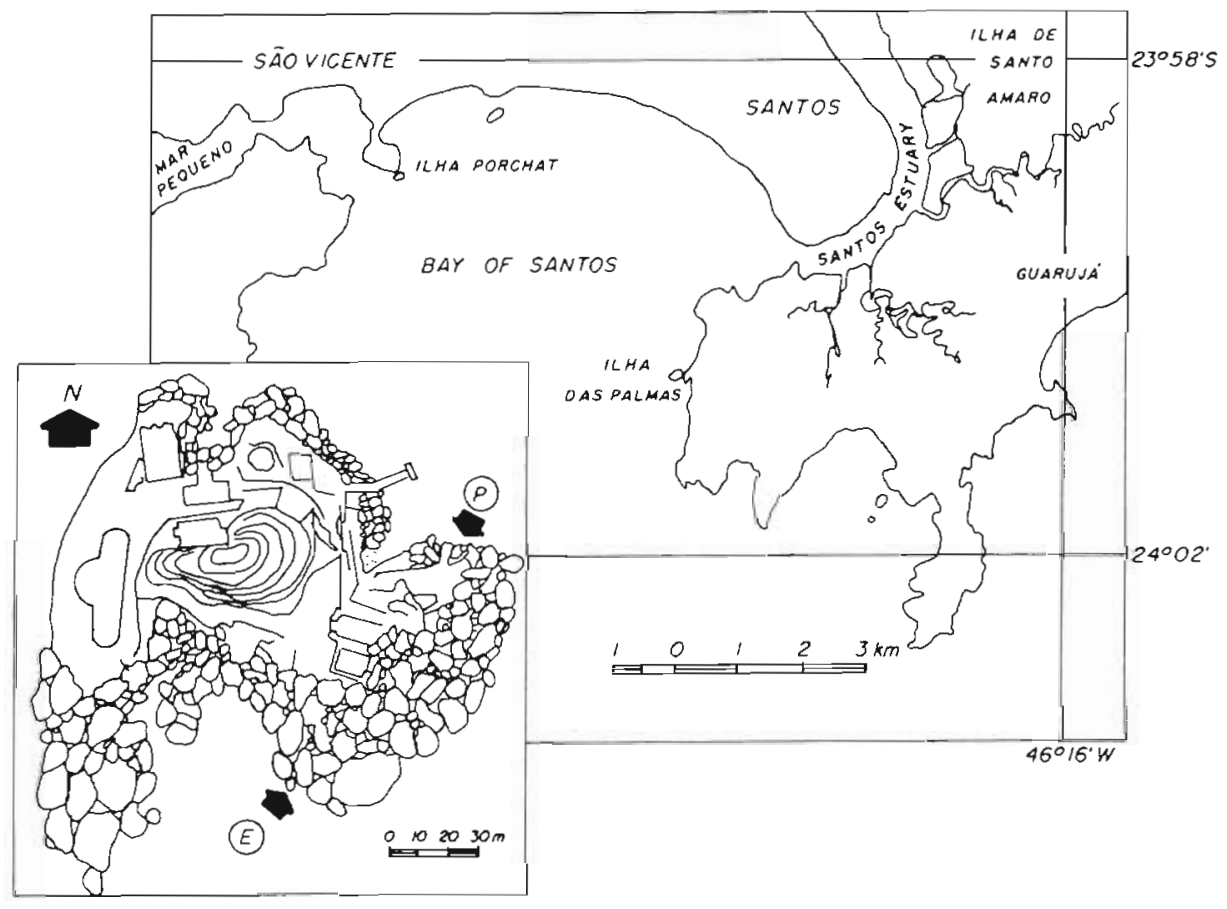

Fig. 1. Map of Bay of Santos showing location of Ilha das Palmas. In detail: Stns $P$ (protected) and $E$ (exposed) 
Burroughs 6900 computer of the University of São Paulo, and on the Digital PDP 11/34 at the Brazilian Naval Research Institute, Arraial do Cabo. Subroutines (FORTRAN IV) appear in Davis (1974) and Lebart \& Fénelon (1971).

The following codes are used (alone or combined) in the tables, figures and throughout the text: $E=$ exposed, $\mathrm{P}=$ protected; $\mathrm{S}=$ summer, $\mathrm{W}=$ winter $\mathrm{I}=$ lower zone, $\mathrm{U}=$ upper zone; $\mathrm{H}=$ high tide, $\mathrm{L}=$ low tide (e.g. EWIL = exposed site, winter, lower zone, low tide).

\section{RESULTS}

\section{Distribution of species}

Sixteen species were identified, of which 7 occurred exclusively at the exposed site and only one exclusively at the protected station. Eight species were common to both mussel beds. The reduced number of species at Stn P contrasted with the diversity found at Stn E. The number of specimens was also lower at $P$, ranging from 13 to 181. Amphipods were more abundant at Stn $E$, especially in summer, with extreme values of 21 and 889 individuals. Density variation was high.

The distribution of each species in the samples is shown in Table 1. Dominant species at the sheltered site were Elasmopus pectenicrus (Bate) followed by Hyale sp. 1, Elasmopus brasiliensis (Dana) and Hyale media (Dana). At the exposed site Jassa falcata (Montagu) dominated, although E. pectenicrus, Hyale sp. 1 , E. brasiliensis and Podocerus brasiliensis (Dana) were also important. These results, as well as major differences in seasonal dominance, are partially related to the reproductive cycles of the species mentioned above. Elasmopus spp. juveniles were common in winter and summer, while $J$. falcata juveniles were extremely abundant in summer, together with Hyale sp. 1 young specimens. The number of other species juveniles was not representative.

In most cases, amphipods were more abundant in the low zones of the mussel beds. During high tides, however, density tended to increase in the upper zones, which suggests that although the beds retain a certain amount of moisture, some amphipods living in the upper zones are forced to migrate to avoid the effects of long exposure to air. An exceptional case was that of hyalids, which were present in high densities in the upper levels, even during low tides.

Tube-dwelling and nestling were the 2 major life styles. Tubicolous species (Ampithoe ramondi Audouin, Corophium acherusicum Costa, Erichthonius brasiliensis and $J$. falcata) were only found at the exposed station, where the dominant $J$. falcata was particularly abundant in the lower zone. Nestlers were dominant as regards number of species. Hyalidae and Gammaridae accounted for the total amount of amphipods at Stn $\mathrm{P}$, since the only inquiline species, Stenothoe valida (Dana), was found only at Stn E.

\section{Multivariate analysis \\ Identification of factors}

The correspondence analysis enabled recognition of 3 main factors accounting for a total of $64.7 \%$ of the data variability. The factorial axes were identified by calculating the absolute contribution of each species and sample to the shaping of each axis. For simplicity, only significant scores are mentioned in the figures.

Axis I ( $23.8 \%$ of variance). The position of the points along the axis reflected a gradient from a loose mat with low percentage of sediment in the substrate composition (e.g. Stn E, low level) towards a dense and compact one, where the amount of sediment was considerable (Stn P, both levels). Consequently, this first axis was defined as a compound parameter combining structural characteristics of the mussel beds, such as number of layers, volume of mytilids, amount of sediment and cavities. These factors depend greatly, but not solely, on wave energy. They also depend on vertical zonation in relation to the tidal height: mussel volume was usually higher in the lower than the upper zones (Table 1).

Axis II (22.4\% of variance). This axis separated samples belonging to the lower zone of both protected and exposed sites from those of the upper zone. It was therefore defined as a zonation factor.

Axis III accounted for $13.5 \%$ of the total variance and appeared to be influenced by a group of environmental factors of which season and tidal height were the most evident. Altogether they reflected the degree of desiccation tolerated by the amphipods. Only nestling species contributed significantly. Tube-dwellers formed an intermediate group, located near the origin. This last group must be protected inside their tubes against desiccation, and would not be so affected by this factor in most cases.

\section{Assemblages}

The projection of samples and species in Plane I-II of the correspondence analysis (CA) (Fig. 2) displayed 4 natural groups, 2 formed by $E$ samples and 2 by $P$ samples. The $E$ samples were grouped according to vertical zonation, respectively lower (Group 1) and upper (Group 2) levels. The majority of the P samples 


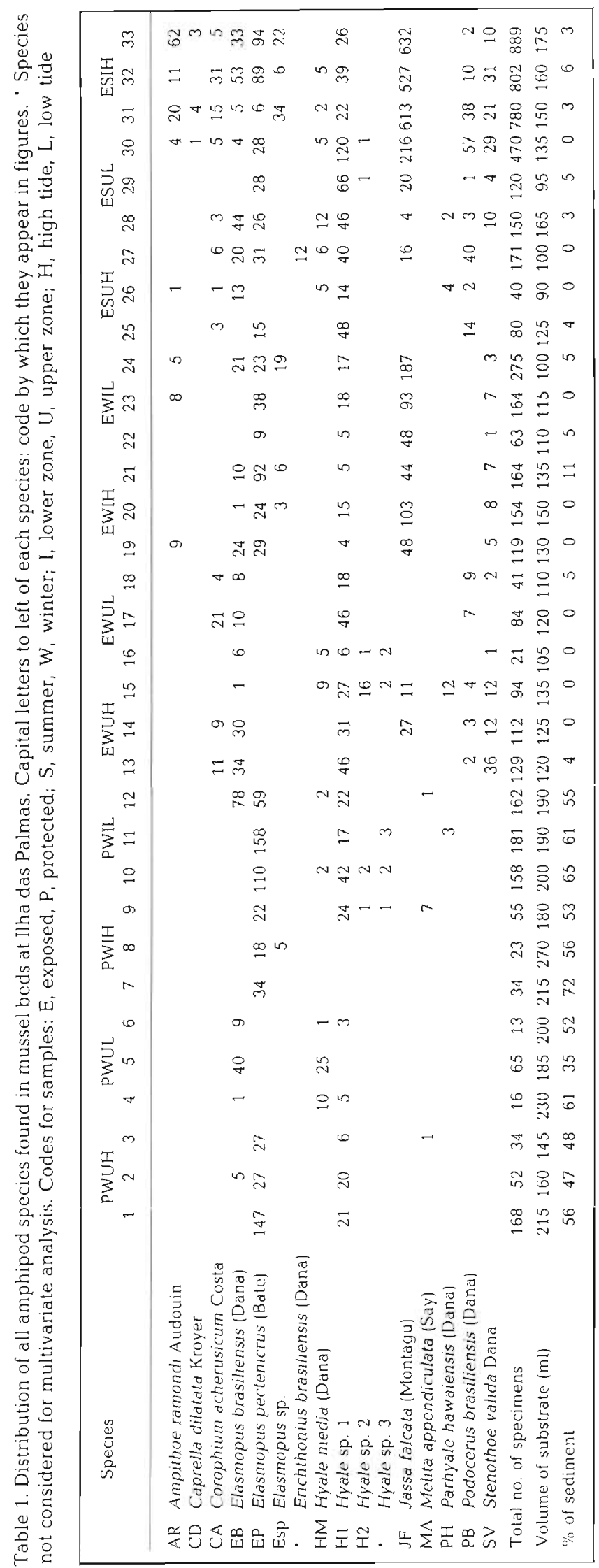

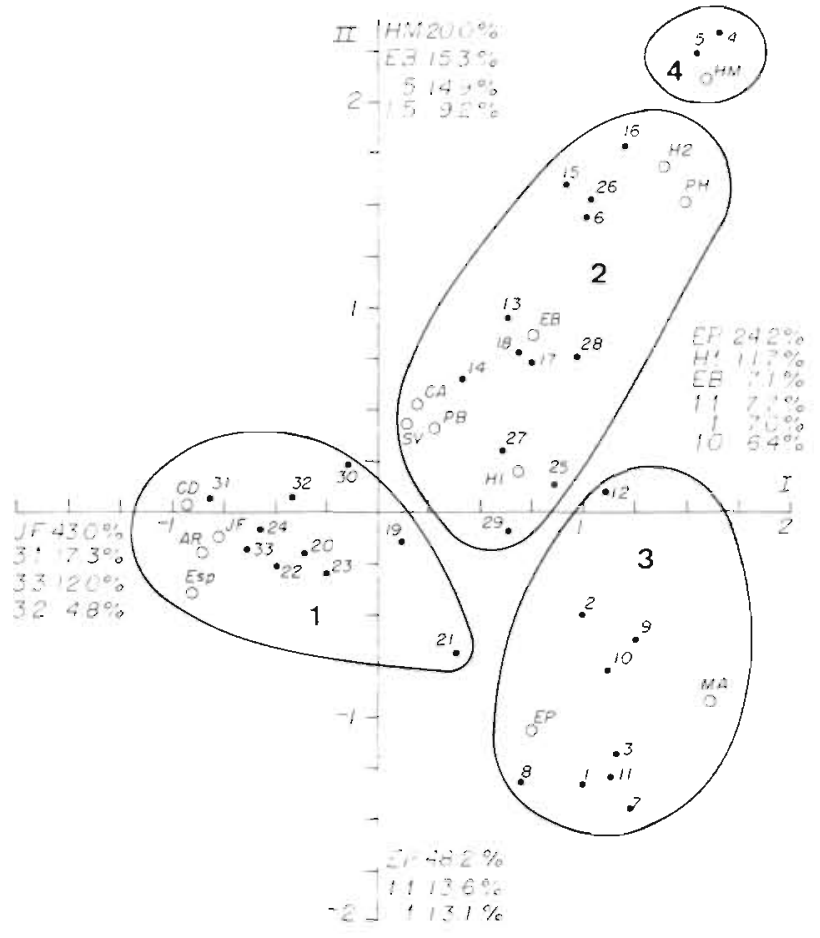

Fig. 2. Correspondence analysis of the amphipod community: Factors I (spatial structure of substrate) and II (vertical zonation). Species and samples with high contributions are indicated in each axis. Main groups are: 1 , exposed, low zone; 2 , exposed, upper zone; 3 and 4 , protected. For codes and abbreviations see Table 1

formed Group 3, except for 2 which were clustered separately as Group 4. In this last assemblage the number of Hyale media specimens exceeded the values normally found at Stn P. The tightness of the mussel mats allied to the more stressing environmental conditions of the upper zones were negatively correlated with the abundance and diversity of amphipods.

The dendrogram display (Fig. 3) obtained from the similarity matrix of samples closely resembles the assemblages depicted in CA's Plane I-II. At a similarity level of approximately 0.60 , the cluster analysis provided 4 main groups. Group A, constituted almost exclusively of $\mathrm{P}$ samples, was characterized by a low number of species and had Elasmopus pectenicrus as the dominant amphipod. This cluster corresponds to Group 3 of the CA. Group B was constituted of EI samples, except for one case, and was characterized by high species richness. E. pectenicrus, Jassa falcata and Stenothoe valida were its most numerous elements This assemblage roughly corresponds to Group 1 of the CA. The largest assemblage, Group $C_{1}$ was composed almost exclusively by EU samples of both seasons. The dominant species was Hyale sp. 1 ; J. falcata and $E$. pectenicrus were not present in such great numbers as in the previous group. Group $\mathrm{C}$ included most of the 


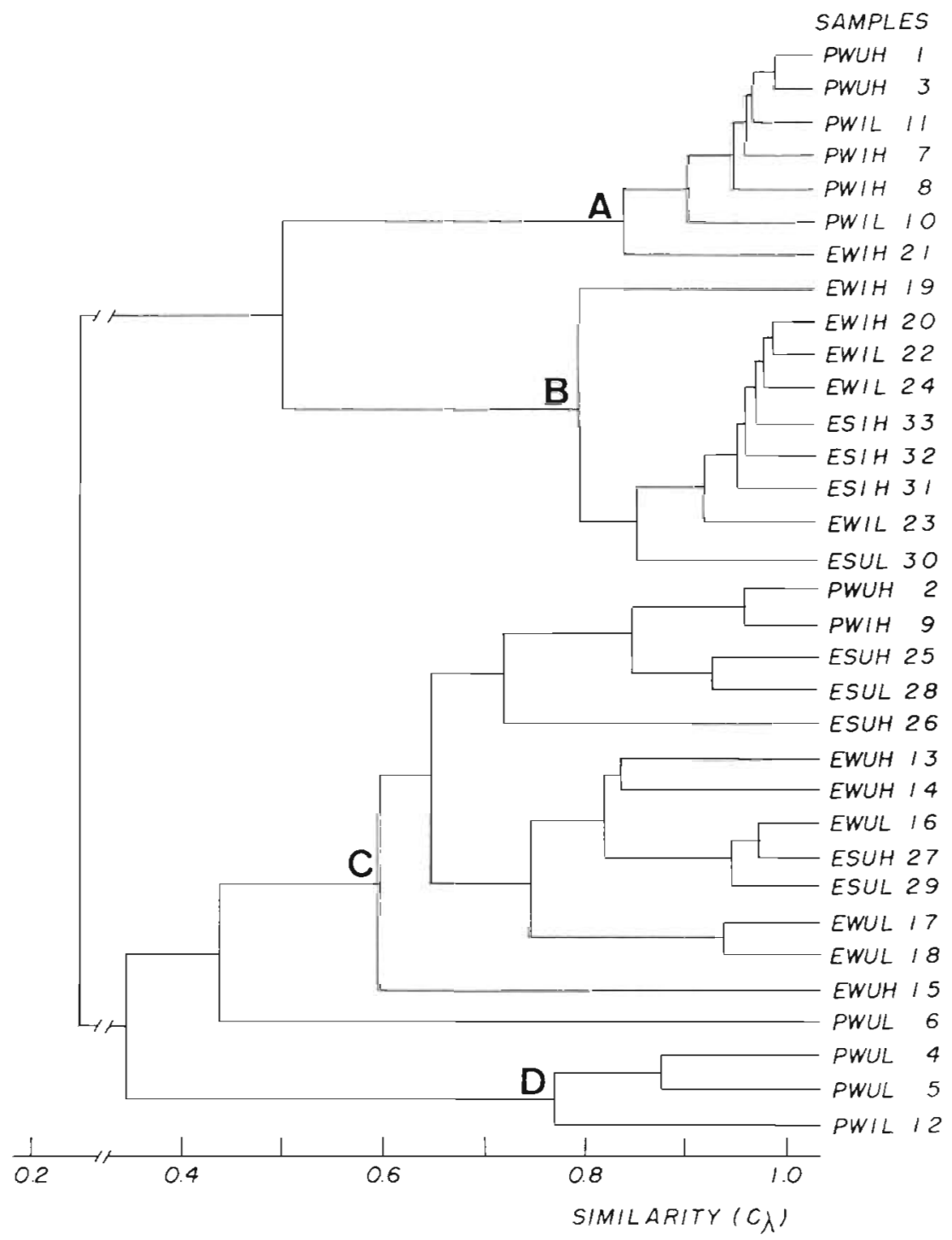

Fig. 3. Dendrogram display of samples derived from the similarity matrix using Morisita's index $\left(C_{i}\right)$. Main groups arc: A, protected, low zone; $B$, exposed, low zone; $C$, exposed, upper zone; $D$, protected. For codes see Table 1 occurrences of Hyale sp. 2 and Parhyale hawaiensis (Dana) at the exposed site. Group D, a small PWL cluster, was characterized by a low diversity and by having as its most frequent amphipods Elasmopus brasiliensis and Hyale media, and matches Group 4 of the $\mathrm{CA}$. Of the 4 factors tested in the sampling program, those most involved in the clustering of samples were vertical zonation and wave exposure. These observations coincide with the CA results.

Groups were not so clearly defined in factorial Plane II-III (Fig. 4) as in Plane I-II. Besides the low contribution from the tube-dwellers, it is interesting to note that the third axis (desiccation) separated Hyale media from Hyale sp. 2. The same occurred with other 2 closely related species, Elasmopus brasiliensis and E. pectenicrus, separated by Axis II (zonation). The dendrogram display of the species cluster (Fig. 5) showed a distribution similar to this plane. There was little similarity between the species. Cases of high proximity were restricted to pairs of species or to very small groups. In these situations, amphipods differed either in abundance (dominants Jassa falcata, Hyale sp. 1, E. pectenicrus and E. brasiliensis were located in different clusters) or in life styles. Two main clusters were delimited: Group A ('sensitive' species), abundant at the lower $E$ level and absent or rare in $P$, and Group B ('tolerant'), whose elements showed a preference for higher levels, also absent in $\mathrm{P}$, except for Hyale sp. 1.

\section{DISCUSSION}

Several papers report the correlation between hydrodynamic conditions and the composition of amphipod assemblages (Fenwick 1976, Wakabara et al. 1983). However, the differences in density, number 


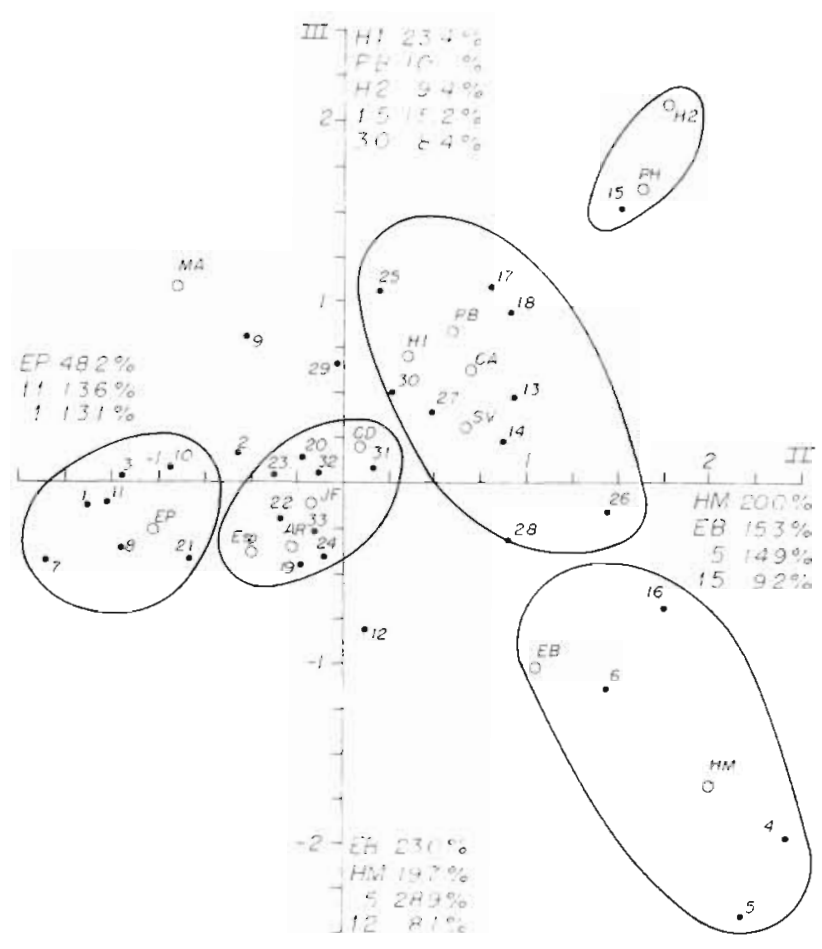

Fig. 4. Correspondence analysis of the amphipod community: Factors II (vertical zonation) and III (desiccation). Species and samples with high contributions are indicated in each axis. For codes and abbreviations see Table 1

of species and exclusive species, verified between Stations $\mathrm{P}$ and $\mathrm{E}$, are not to be attributed only to the mechanical effects of wave action, but also, and more critically, to 'side' effects such as turbidity and sediment deposition, as suggested by Moore (1978).

Although sediment contributes to the spatial heterogeneity of a habitat and represents a separate substrate category in mussel beds (Tsuchiya \& Nishihira 1985), an excess of it seems to negatively affect the amphipod assemblage, as in the case of Stn P. The deposition of particles helps to create unfavourable conditions in the mussel beds both by obstructing refuges and lowering the oxygen tension. In mussel areas fine particles derived from the faeces and pseudofaeces of these bivalves can hamper the settlement of some species, by clogging respiratory or feeding structures. The availability of adequate refuges for clinging or creeping organisms (as is the case of amphipods) has already been negatively correlated with the amount of sediment (Hagermann 1966, Tsuchiya \& Nishihira 1985).

The dominant species were the same at both sites, except for Jassa falcata, a tube-dweller which occurred exclusively at Stn E. Its presence is essentially induced by severe hydrodynamic conditions and it is a dominant element in polluted waters (Nair \& Anger 1979, Desrosiers et al. 1982) such as the present case. However, the habitat preferences of the other tubicolous amphipods differed from literature data. In this study no tube-dwellers were found at the sheltered site, while Wakabara et al. (1983) reported that Ampithoe ramondi and Erichthonius brasiliensis associated with Sargassum occur only at sheltered sites in nearby regions. Also, Moore (1978) mentioned the preference of

SPECIES

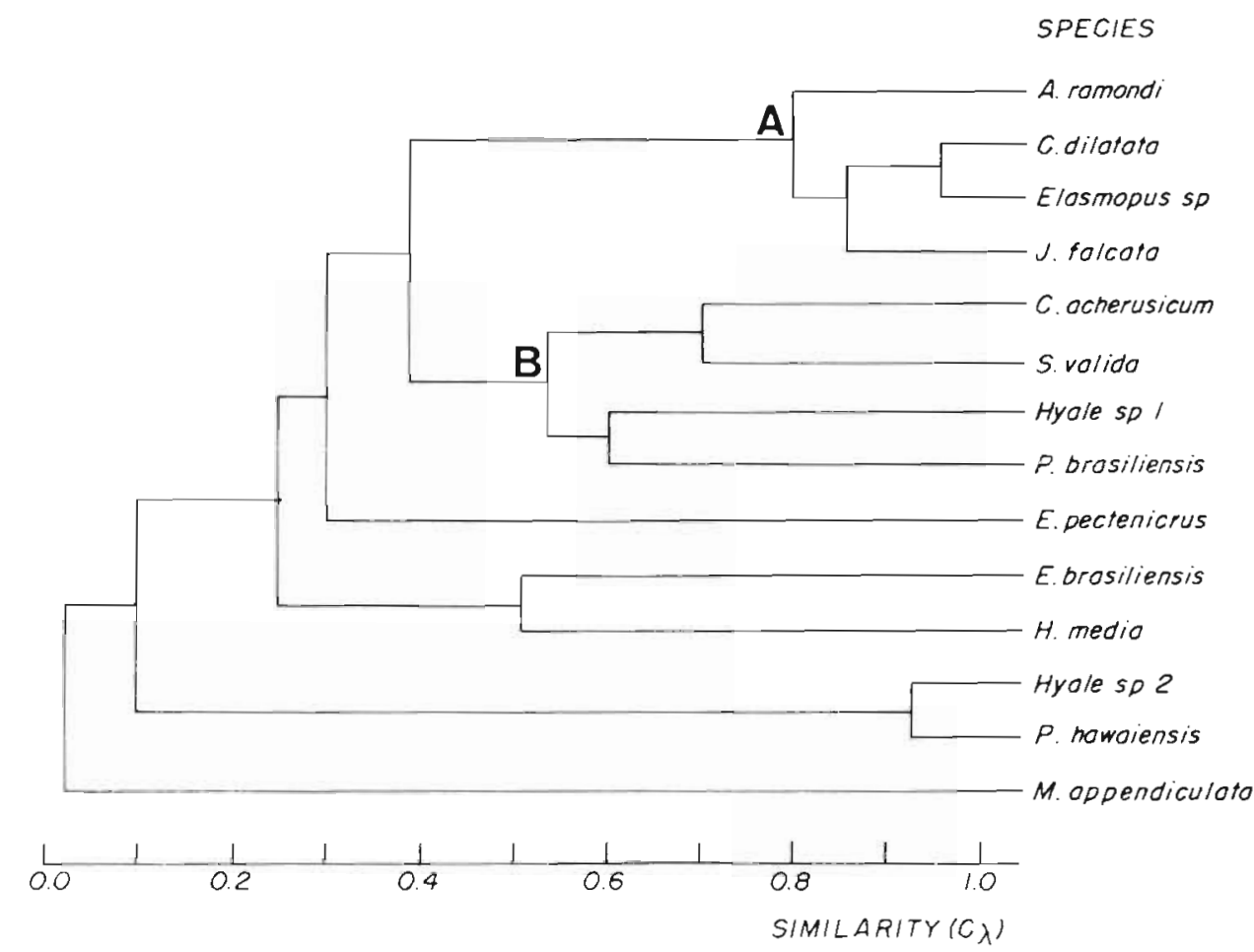

Fig. 5. Dendrogram display of species derived from the similarity matrix using Morisita's index (C, ). Main groups are: $A$, 'sensitive' species; B, 'tolerant' species 
Corophium acherusicum for clear waters (as opposed to turbid) and protected areas. These contradictory results draw attention to the physical structure of mussel beds: these habitats provide an efficient shelter on exposed coasts, but would hinder colonization of some species in sheltered areas due to excess of sediment. Only Melita appendiculata (Say) is reported to live in association with sand and biodetritic sediments (Wakabara 1972) and could have benefited from the conditions at Stn P. However, its low frequency and density suggests that even in this case the excess of debris interfered negatively. This species was not found at the exposed station presumably because of lack of an adequate sandy substrate.

The importance of wave shock as an indirect factor in the selection of species was reflected in the multivariate analyses. The groups formed in Plane I-II of the $\mathrm{CA}$ and in the sample cluster were more related to the percentage of sediment in the substrate and to the architecture of the mussel beds than to the wave energy itself. The analyses also made clear that the samples from the exposed site were a more homogeneous group than those from the protected site, and this was interpreted as a consequence of the stressful environmental conditions for amphipods at Stn P already mentioned.

The correspondence analysis helped to elucidate the problem of coexistence of amphipods belonging to closely related species. Two cases are worth discussing. Elasmopus brasiliensis and E. pectenicrus occupied the same microenvironment, except that the former was more abundant in the upper zones of the mussel beds. This may indicate a difference in tolerance to oxygen tension, or other related factors: Agnew \& Taylor (1985) associated this tolerance with the vertical distribution of gammarids. The other remarkable case was that of 2 hyalids. It is known that some species such as Hyale media are fairly resistant to anaerobic conditions (Wieser \& Kanwisher 1959). Hyalids could benefit from this tolerance by not migrating to lower zones during the ebb tides, therefore avoiding heavy predation. Axis III, associated with desiccating factors, separated $H$. media from Hyale $\mathrm{sp} .1$, the former preferring low tides. The ability of $H$. media to tolerate this kind of stress could also be an advantage to coexist with the dominant Hyale sp. 1.

The difference in physiological tolerance such as the 2 examples mentioned above account in part for the presence in the same habitat of closely related species. These differences are fully explored in the intertidal region, as resource partitioning can also be achieved, for example, through high and low tide conditions. Only few species had very similar niches according to the multivariate analyses. In these cases, the species belonged to far related families, which would diminish the risk of dietary overlaps. In any case, if food preferences may coincide among some elements of the order (Nelson 1979), the food factor in the mussel areas cannot be classified as limiting, as a great number of amphipods are presumably omnivorous (Macko et al. 1982. Wakabara et al. 1983) and a great variety of food items, including algae and detritus, are available in abundance.

The majority of the amphipods found in the mussel beds at Ilha das Palmas are common in the region. Most of them are frequent inhabitants of algae (Wakabara 1972, Masunari 1982, Wakabara et al. 1983) and reefs of Phragmatopoma (Tararam et al. 1978). However, the dominant amphipods in these substrates are not the same, reflecting the particular lodging qualities of each habitat.

Acknowledgements. This work is based on a dissertation submitted in partial fulfillment of the requirements for a M.Sc. degree at the University of São Paulo. The research was supported by a scholarship from the Conselho Nacional de Desenvolvimento Científico e Tecnológico (CNPq), Brazil. I am particularly grateful to Dr. Liliana Forneris for discussion and advice throughout the study and to Dr. Jean L. Valentin (Brazilian Naval Research Institute) for critical reading of the manuscript and for helpful suggestions regarding multivariate analysis. The valuable comments of 3 anonymous reviewers are duly acknowledged. I thank Drs. Yoko Wakabara and Fosca P. P. Leite for their help in species identification.

\section{LITERATURE CITED}

Agnew, D. J., Taylor, A. C. (1985). The effect of oxygen tension on the physiology and distribution of Echinogammarus pirlotti (Sexton \& Spooner) and E. obtusatus (Dahl) (Crustacea: Amphipoda). J. exp. mar. Biol. Ecol. 87: $169-190$

Biernbaum, C. K. (1979). Influence of sedimentary factors on the distribution of benthic amphipods of Fishers Island Sound, Connecticut. J. exp. mar. Biol. Ecol. 38: 201-223

Chardy, P., Glemarec, M., Laurec, A. (1976). Application of inertia methods to benthic marine ecology: practical implications of the basic options. Estuar. coast. Mar. Sci. 4: $179-205$

Davis, J. C. (1974). Statistics and data analysis in geology. John Wiley \& Sons, New York

Dean, T A. (1981). Structural aspects of sessile invertebrates as organizing forces in an estuarine fouling community. J. exp. mar. Biol. Ecol. 53: 163-180

Desrosiers, G., Bellan-Santini, D., Brêthes, J.-C. (1982). Evolution spatio-temporelle des peuplements de substrats rocheux superficiels dans un golfe soumis à des multiples pollutions (Golfe de Fos, France). Téthys 10: 245-253

Edgar, G. J. (1983). The ecology of South-East Tasmanian phytal animal communities. IV. Factors affecting the distribution of ampithoid amphipods among algae. J. exp. mar. Biol. Ecol. 25: 1-18

Fenwick, G. D. (1976). The effect of wave exposure on the amphipod fauna of the alga Caulerpa brownii. J. exp. mar. Biol. Ecol. 25: 1-18

Fernandes, F. C. (1981). Aspectos biológicos e ecológicos do mexilhào Perna perna (Linné, 1758) da região do Cabo 
Frio - Brasil. Ph. D. thesis, Oceanographic Institute, University of São Paulo

Hagermann, L. (1966). The macro- and microfauna associated with Fucus serratus L., with some ecological remarks. Ophelia 3: 1-43

Hill, M. O. (1974). Correspondence analysis: a neglected multivariate method. Appl. Statist. 23: 340-354

Jacobi C. $M$. (in press). The invertebrate fauna associated with intertidal beds of the brown mussel Perna perna (L.) from Santos, Brazil. Studies Neotrop. Fauna 21

Lebart, L., Fénelon, J.-P. (1971). Statistique et informatique appliquées. Dunod, Paris

Legendre, L., Legendre, P. (1984). Ecologie numérique. Masson, Paris

Macko, S. A., Lee, W. Y., Parker, P. L. (1982). Nitrogen and carbon isotope fractionation by two species of marine amphipods: laboratory and field studies. J. exp. mar. Biol. Ecol. 63: 145-149

Masunari, S. (1982). Organismos do fital Amphiroa beauvoisii Lamouroux, 1816 (Rodophyta: Corallinaceae). I. Autoecologia. Bolm. Zool. Univ. São Paulo 7: 57-148

McBane, C. D., Crocker, R. A. (1983). Animal-algae relationships of the amphipod Hyale nilssoni (Ratke) in the rocky intertidal. J. Crust. Biol. 3: 592-601

Moore, P. G. (1978). Turbidity and kelp holdfast Amphipoda I. Wales and S. W. England. J. exp. mar. Biol. Ecol. 32: 53-96

Nair, K. K. C., Anger, K. (1979). Experimental studies on the life cycle of Jassa falcata (Crustacea, Amphipoda). Helgoländer wiss. Meeresunters. 32: 442-452

Nelson, W. G. (1979). An analysis of structural pattern in an eelgrass (Zostera marina L.) amphipod community. J. exp. mar. Biol. Ecol. 39: 231-264

Stoner, A. W (1980). Perception and choice of substratum by epifaunal amphipods associated with seagrasses. Mar. Ecol. Prog. Ser. 3: 105-111

Stoner, A. W. (1985). Penicillus capitatus: an algal island for macrocrustaceans. Mar. Ecol. Prog. Ser. 26: 279-287

Tararam, A. S., Wakabara, Y., Leite, F. P. P. (1978). Notes on Parhyale hawaiensis (Dana), Crustacea-Amphipoda. Bull. mar. Sci. 28: 782-785

Tsuchiya, M., Nishihira, M. (1985). Islands of Mytilus as a habitat for small intertidal animals: effect of island size on community structure. Mar. Ecol. Prog. Ser. 25: 71-81

Wakabara, Y. (1972). Espécies da família Gammaridae (Crustacea-Amphipodal entre as latitudes $03^{\circ} 23^{\prime} \mathrm{E} 38^{\circ} 05^{\prime} \mathrm{S}$ do Atlântico Ocidental. Ph. D. thesis, University of São Paulo

Wakabara, Y., Tararam, A. S., Takeda, A. M. (1983). Comparative study of the amphipod fauna living on Sargassum of two Itanhaem shores, Brazil. J. Crust. Biol. 3: 602--607

Wieser, W., Kanwisher, J. (1959). Respiration and anaerobical survival in some sea-weed inhabiting invertebrates. Biol. Bull. mar. biol. Lab., Woods Hole 117: 594-600

Wolda, H. (1981). Similarity indices, sample size and diversity. Oecologia (Berl.) 50: 296-302 